\title{
SEC31A wt Allele
}

National Cancer Institute

\section{Source}

National Cancer Institute. SEC31A wt Allele. NCI Thesaurus. Code C101476.

Human SEC31A wild-type allele is located in the vicinity of $4 \mathrm{q} 21.3$ and is approximately 83 $\mathrm{kb}$ in length. This allele, which encodes protein transport protein Sec31A, is involved in protein trafficking. 